\title{
ANALISIS ISU S (SUKU) A (AGAMA) R (RAS) A (ANTAR GOLONGAN) DI MEDIA SOCIAL INDONESIA
}

\author{
Lidya Wati Evelina \\ Dosen Ekonomi dan Komunikasi \\ Universitas Bina Nusantara \\ Email: lidiaevelina@yahoo.com / lavelina@binus.edu
}

\begin{abstract}
Abstrak
Tujuan Penelitian: Untuk mengetahui konten-konten di media sosial yang berkaitan dengan Isu SARA di Indonesia dari tahun 2013 hingga 2015. Untuk mengetahui alasan perlunya Etika Bermedia sosial dalam konteks masyarakat multietnis. Teori yang digunakan dalam penelitian ini adalah Cyberculture meliputi relasi antara nature dan technology. Pesan dalam cyber culture bila merupakan sebuah pesan yang memperkenalkan sebuah aksi atau reaksi. Metode Penelitian yang digunakan adalah metode kualitatif deskriptif dengan melakukan wawancara semi terstruktur dengan para informan yang sudah dipilih dan sesuai objek penelitian (purposive sampling) dan literature review. Teknik validasi yang dipakai yaitu dengan mewawancara pengamat dan pakar social media. Analisis data menggunakan reduksi data. Hasil penelitian: Dalam Tahun 2013 hingga 2015 terdapat beberapa isi media sosial yang bermuatan Suku, Agama, Ras dan Antar Golongan yang menimbulkan konflik di masyarakat multietnis seperti Indonesia. Hal itu terjadi karena masyarakat penggunan media sosial belum memahami etika bermedia sosial. Akibat ketidakpahaman terhadap etika bermedia sosial berdampak pada masalah hukum. Peran pendidikan sangat diperlukan untuk mensosialisasikan etika bermedia sosial. Pemerintah perlu membuat kebijakan khusus dengan memberdayakan masyarakat melalui jalur pendidikan, komunitas dan organisasi kemasyarakatan agar paham etika komunikasi dalam penggunaan media sosial. Caranya mengaktifkan Etika bermedia sosial yang melibatkan peran masyarakat dan Kalangan industri. (LE)
\end{abstract}

Kata Kunci: content, di Indonesia, isu SARA, social media 


\section{Pendahuluan}

Sepuluh tahun belakangan (2005) jenis smartphone GSM sudah mulai dikenalkan dengan sistem operasi berbasis Android di California, Amerika Serikat. Hal tersebut berdampak pada meningkatnya pengguna Telpon seluler dengan aneka pilihan merk produk telpon seluler. Harga smartphonepun sudah sangat murah dan bukan merupakan barang mewah lagi di Indonesia. Smartphone bisa diperoleh dengan harga mulai sekitar Rp. 500.000,- (lima ratus ribu rupiah).

Banyak pengguna telpon seluler juga berdampak terhadap semakin banyaknya pengguna Internet. Tingginya pengguna internet di Indonesia adalah salah satu faktor pendukung perkembangan jejaring-jejaring situs pertemanan dan informasi tersebut di Indonesia. Menurut Data Lembaga Survei AC Nielsen, pada tahun 2014 ini, jumlah pengguna internet atau internet user di Indonesia diperkirakan mencapai 71 juta users. Dari jumlah itu, 41 juta di antaranya mengakses lewat smarthphone serta 70 juta di antaranya mengakses sosial media seperti Facebook, Twitter, Path, Instagram, LinkedIn, Google+ untuk menyebut beberapa media sosial yang sangat populer.

Pada masyarakat urban seperti sekarang ini, penggunaan gadget atau smartphone merupakan benda yang wajib dibawa tiap harinya untuk melakukan interaksi satu sama lain. Munculnya berbagai aplikasi seru menjadi daya tarik untuk menemani penggunanya.

Survei Data Global Web Index menunjukkan bahwa Indonesia adalah Negara yang memiliki pengguna internet terbesar di Asia Tenggara dan memiliki pengguna sosial media paling aktif di asia. Indonesia memiliki 79,7\% user aktif di social media mengalahkan Filipina $78 \%$, Malaysia $72 \%$, Cina $67 \%$.

Iwan Setyawan, pengamat social media (tahun 2010 -2012), dalam acara Sudut Pandang di Metro TV mengatakan tel- ah melakukan studi tentang social media di Indonesia. Hasilnya adalah percakapan terbesar di social media yang utama adalah social expression, seperti perasaan senang, galau dan sedih. Hal yang kedua adalah membicarakan tentang rutinitas mulai dari bangun tidur sampai mau tidur, seperti tidur, sekolah, makan. Ketiga, adalah orang yang membicarakan hal yang sedikit lebih serius sampai akhirnya orang membicarakan tentang politik.

Hasil penelitian Iwan bahwa curhat di social media dapat melegakan secara emosional dan bahkan merupakan channel yang bisa menyembuhkan orang. Namun, perlu diingatkan berpendapat di social media sangatlah mudah dan perlu diingat pula menyebarnya sangat mudah juga sehingga bisa menimbulkan berbagai macam resiko dan tak jarang berujung ke masalah hukum.

Baranews.co menulis ada 25 kasus status sosial media yang berujung ke ranah hukum dan beberapa di antaranya berkaitan dengan isu SARA. Hal tersebut menimbulkan kekuatiran akan terjadinya perpecahan pada masyarakat multietnis di Indonesia.

Dari latar belakang di atas, dapat dirumuskan masalah penelitian, yaitu (1) Apa saja konten-konten di media sosial yang berkaitan dengan Isu SARA di Indonesia? (2) Mengapa perlu adanya Etika Bermedia sosial dalam konteks masyarakat multietnis di Indonesia?

\section{Metodologi}

Pendekatan penelitian ini adalah pendekatan kualitatif. Penelitian kualitatif yaitu penelitian yang bermaksud untuk memahami fenomena tentang hal yang dialami subjek penelitian secara holistik, dan dengan cara deskripsi dalam bentuk kata- kata dan bahasa, pada suatu konteks khusus yang alamiah dan dengan memanfaatkan berbagai metode ilmiah (Moleong, 2008:6).

Pada obyek penelitian ini, peneliti dapat mengamati secara mendalam aktivitas 
(activity) orang-orang (actors) yang ada pada tempat (place) tertentu (Sugiyono, 2008:215). Objek penelitian pada penelitian ini adalah interaksi dari masyarakat Indonesia yang mengandung kasus SARA di media sosial.

Subjek penelitian merupakan sumber data yang dimintai informasinya sesuai dengan masalah penelitian. Adapun yang dimaksud sumber data dalam penelitian adalah subjek dari mana data diperoleh (Arikunto, 2005:107). Untuk mendapat data yang tepat maka perlu ditentukan informan yang memiliki kompetensi dan sesuai dengan kebutuhan data (purposive). Adapun yang menjadi subjek penelitian ini adalah: (1) Pakar Komunikasi New Media dan Penulis Buku Social Media, (2) Pakar Komunikasi Antar Budaya, (3) Pengamat social media. (4) Pengguna social media (Facebook, Twitter dan Path).

\section{Teknik Pengumpulan Data}

Menurut Lofland sumber data utama dalam penelitian kualitatif adalah kata-kata dan tindakan. Selebihnya adalah data tambahan seperti dokumen dan lain lain (Moleong, 2008). Penelitian kualitatif mementingkan pada kedalaman atau kualitas data. Jadi informan yang dibutuhkan adalah orang-orang yang berkompeten serta menguasai data-data yang dibutuhkan dalam penelitian ini. Ada tiga sumber data dalam penelitian kualitatif, yang juga digunakan dalam penelitian ini yaitu wawancara, observasi, dan studi dokumen.

Bogdan dalam Moleong (2008) mendefinisikan observasi sebagai penelitian yang bercirikan interaksi sosial yang memakan waktu cukup lama antara peneliti dengan subjek dalam lingkungan subjek, dan selama itu data dalam bentuk catatan lapangan dikumpulkan secara sistematis dan berlaku tanpa gangguan. Creswell (2007) menyarankan beberapa petunjuk dalam melakukan observasi, yaitu: (1) Pilih waktu dan lokasi observasi. Dapatkan persetujuan terlebih dahulu untuk memperoleh akses. (2) Tentukan siapa, apa, dan berapa lama observasi dilakukan. (3) Tekankan peran Anda sebagai peneliti. Peran ini bisa saja sebagai orang yang terlibat sampai orang yang meneliti. Lebih baik berdiri sebagai orang luar yang dipandu oleh orang dalam. (4) Buatlah tata cara observasi. (5) Ingatlah hal berikut, seperti ekspresi informan, penampilan, kegiatan, acara yang saat itu terjadi, dan reaksi Anda sendiri. (6) Apabila memunkinkan Anda dibantu dalam hal teknis. (7) Setelah selesai, tinggalkan lokasi secara sopan dan jangan lupa berterima kasih.

Untuk sumber data sekunder, berasal dari sumber tertulis. Penulis melakukan studi dokumen dengan mengamati pemberitaan mengenai konflik yang terjadi karena interaksi di media sosial di internet. Selain itu penulis juga akan melakukan studi pustaka melalui buku-buku, khususnya yang berhubungan dengan media baru dan media sosial.

\section{Metode Analisis Data}

Metode analisis data yang peneliti gunakan adalah metode analisis data deskriptif, karena penelitian ini bertujuan mengamati perilaku penggunaan social media selama tahun 2014 dan tahun 2015 di Indonesia yang mengandung kasus SARA, dan untuk mengetahui apakah mereka memperhatikan etika berkomunikasi di media sosial.

Menurut Arikunto (2005:250) metode analisis deskriptif merupakan penelitian bukan eksperimen, karena tidak dimaksudkan untuk mengetahui akibat dari suatu perlakuan. Dengan penelitian deskriptif peneliti hanya bermaksud menggambarkan (mendeskripsikan) atau menerangkan gejala yang sedang terjadi.

Bogdan dalam Sugiyono (2008:88) menyatakan bahwa analisis data adalah proses mencari dan menyusun data secara sistematis data yang diperoleh dari hasil wawancara, catatan lapangan, dan bahan-bahan lain, sehingga dapat mudah dipahami dan temuannya dapat diinformasikan kepada orang lain.

Sedangkan dalam Sugiyono (2008:89) 
berpendapat bahwa analisis data adalah proses mencari dan menyusun secara sistematis data yang diperoleh dari hasil wawancara, catatan lapangan, dan dokumentasi, dengan cara mengorganisasikan data ke dalam kategori, menjabarkan kedalam unit-unit, melakukan sintesa, menyusun ke dalam pola, memilih yang penting dan yang akan dipelajari, dan membuat kesimpulan sehingga mudah difahami diri sendiri maupun orang lain.

Prosedur dalam menganalisis data kualitatif, menurut Miles dan Huberman dalam Sugiyono (2008:91-99) adalah sebagai berikut : (1) Reduksi Data berarti merangkum, memilih hal-hal yang pokok, memfokuskan hal-hal yang penting, dicari tema dan polanya. (2) Penyajian Data, setelah data direduksi, selanjutnya mendisplaykan data. Dalam penelitian kualitatif, penyajian data bisa dilakukan dalam bentuk uraian singkat, bagan, hubungan antar kategori, flowchart dan sejenisnya dengan menggunakan teks yang bersifat naratif. (3) Kesimpulan atau Verifikasi, langkah ketiga dalam analisis data kualitatif adalah penarikan kesimpulan dan verifikasi. Kesimpulan awal yang dikemukakan masih bersifat sementara, dan berubah bila tidak ditemukan bukti-bukti yang kuat yang mendukung pada tahap pengumpulan data berikutnya. Apabila kesimpulan pada tahap awal, didukung bukti-bukti yang valid dan konsisten saat peneliti kembali kembali ke lapangan mengumpulkan data, maka kesimpulan merupakan kesimpulan yang kredibel.

\section{Keabsahan Data}

Tujuan pengecekan keabsahan data ini untuk memperoleh data yang terpercaya. Dalam menetapkan keabsahan data diperlukan teknik pemeriksaan. Pelaksanaan teknik pemeriksaan didasarkan atas sejumlah kriteria yang digunakan. Dalam penelitian kualitatif penilaian kualitas penelitian menggunakan kriteria derajat kepercayaan (credibilitas), keteralihan (transferability), kebergantungan (dependability) dan kepastian (confirmability) (Moleong, 2008: 173-174).

Triangulasi adalah teknik pemeriksaan data yang memanfaatkan sesuatu di luar data itu. Triangulasi meliputi triangulasi sumber, penyidik, teori, dan metode. Oleh karenanya, pemeriksaan kabsahan data dalam penelitian ini dilakukan dengan cara triangulasi. Pemeriksaan keabsahan data lain, seperti yang direkomendasikan Moleong (2008), dilakukan dengan cara uraian rinci, kecukupan referensial, dan auditing.

Dalam usaha mencari keabsahan data dari penelitian ini, maka peneliti berusaha memenuhi standar dengan melakukan triangulasi. Seperti yang dinyatakan Denzin dalam Bungin (2007:256), maka pelaksanaan teknis dari langkah pengujian keabsahan terdapat empat triangulasi yaitu peneliti, sumber, metode, dan teori.

Dalam penelitian ini, peneliti menggunakan triangulasi sumber untuk memeriksa keabsahan data, yaitu dengan membandingkan keadaan dan perspektif seseorang dengan berbagaipendapat danpandangan orang seperti rakyat biasa, orang yang berpendidikan menengah atau tinggi, orang berada, atau orang pemerintahan, yang pada akhirnya akan diketahui berbagai pendapat dan pemikiran yang berbeda.

\section{Hasil Penelitian}

Indonesia adalah Negara ke 6 terbesar pengguna internet. Di atas Indonesia, untuk saat ini lima besar negara pengguna internet di dunia secara berurutan diduduki Tiongkok, Amerika Serikat, India, Brazil, dan Jepang.

Berdasarkan Data BPS, jumlah penduduk Indonesia adalah 252,4 Juta orang. Pada tahun 2013 penetrasi pengguna internet mencapai mencapai $28,6 \%$ dari 252,4 Juta penduduk Indonesia. Tahun 2015 terjadi kenaikan, menjadi $34,9 \%$. Ternyata, $85 \%$ dari jumlah pengguna internet di Indonesia menggunakan perangkat seluler saat berselancar di 
dunia maya.

Data menunjukkan bahwa jumlah pengguna internet di Indonesia setiap tahunnya meningkat. Peningkatan penggunaan Internet dapat dilihat dari 3 tahun terakhir, seperti dalam tabel di bawah ini:

\section{Tabel: 1: Perbandingan Penggunaan Internet 3 Tahun Terakhir}

\begin{tabular}{|c|c|c|}
\hline $\begin{array}{c}\text { Tabel Tahun } \\
2013\end{array}$ & $\begin{array}{c}\text { Tabel Tahun } \\
2014\end{array}$ & $\begin{array}{c}\text { Tabel Tahun } \\
2015\end{array}$ \\
\hline $\begin{array}{l}\text { Pengguna } \\
\text { internet di } \\
\text { Indonesia } \\
\text { mencapai } 63 \\
\text { juta orang. }\end{array}$ & $\begin{array}{l}\text { Pengguna } \\
\text { internet di } \\
\text { Indonesia } \\
\text { mencapai } 82 \\
\text { juta orang. }\end{array}$ & $\begin{array}{l}\text { Pengguna } \\
\text { internet di In- } \\
\text { donesia men- } \\
\text { capai angkat } \\
88,1 \text { Juta. }\end{array}$ \\
\hline
\end{tabular}

Penggunaan internet dalam 3 tahun belakangan mengalami peningkatan yang signifikan. Sedangkan penggunaan Internet untuk mengakses aplikasi Jejaring sosial sebesar 87,4 \%. Selain Facebook dan Twitter yang terbesar penggunanya di Indonesia. Jejaring sosial lain yang cukup popular di Indonesia adalah Path dengan jumlah pengguna 700.000 di Indonesia.. Sekitar 28 juta pengguna aktif yang memakai perangkat mobile per harinya dan 55 juta pengguna aktif yang memakai perangkat mobile dalam pengaksesannya per bulan.

Menurut data penelitian tahun 2012 bahwa orang Indonesia termasuk orang yang cerewet di social media, terutama orang yang tinggal di kota Jakarta mengalahkan Tokyo, Brazil, London, San Paulo, New York. Bandung termasuk kota paling cerewet urutan keenam. Indikatornya adalah frekuensi dari tweet yang dilakukan 1.058 tweet publik sepanjang Juni 2012.

Sekitar $30 \%$ dari populasi Indonesia aktif di media sosial dan percakapan yang paling panas justru terjadi di sana karena masyarakat lebih cenderung merujuk ke media sosial untuk mengetahui isu terkini dan perkembangan sebuah peristiwa. Kecenderun- gan ini otomatis mengubah cara kerja banyak profesi, tidak terkecuali wartawan dan aparat pemerintah (bbc.co.uk, 2014)

Ternyata,pengguna Internet ternyata lebih banyak wanita daripada kaum pria. Di Jakarta, 73\% pengguna internet didominasi oleh kaum wanita. Internet yang paling banyak digunakan adalah media sosial sebesar $87 \%$ saat terhubung ke internet. Menurut data dari Webershandwick, perusahaan Public Relations dan pemberi layanan jasa komunikasi, untuk wilayah Indonesia ada sekitar $\mathbf{6 5}$ juta pengguna Facebook aktif. Sebanyak 33 juta pengguna aktif per harinya, 55 juta pengguna aktif yang memakai perangkat mobile dalam pengaksesannya per bulan dan sekitar 28 juta pengguna aktif yang memakai perangkat mobile per harinya.

Pengguna Twitter, berdasarkan data PT Bakrie Telecom, memiliki 19,5 juta pengguna di Indonesia dari total 500 juta pengguna global. Twitter menjadi salah satu jejaring sosial paling besar di dunia sehingga mampu meraup keuntungan mencapai USD 145 juta.

\section{Isu Sara di Media Sosial 3 Tahun Terakhir (Tahun 2013 sampai 2015)}

Sepanjang tahun 2013 hingga 2015 di Indonesia, ada beberapa data di media online yang mengungkapkan bahwa interaksi di media sosial mengandung unsur SARA dan berujung ke laporan polisi. Peristiwa memang masih lebih banyak terjadi di media sosial Twitter dan Facebook daripada di Path. Konflik yang terjadi di media sosial di antaranya beberapa berawal dari masalah personal yang berkembang menjadi masalah Suku, Agama, Ras dan Antar Golongan. Kasus-kasus sepanjang tahun 2013 hingga tahun 2015 sebagai berikut:

\section{Tahun 2013 \\ Isu Ras- di Media Sosial Twitter}

Farhat Abas menghina Ahok di media sosial Twitter. Kicauan Farhat yang diunggah 
dalam akuntwitter@farhatabbaslaw adalah

"Ahok protes, Dasar Ahok plat Aja diributin! Apapun plat nya tetap Cina!”.

Tweet Farhat menuai reaksi keras dari banyak kalangan. Pengacara, Ramdan Alamsyah, mewakili Komunitas Interlektual Masyarakat Betawi (KIMB) bahkan melaporkan Farhat ke polisi. Tokoh Muslim Tionghoa, Anton Medan juga ikut melaporkan Farhat ke Polda Metro Jaya.

Dalam laporan resmi bernomor LP/82/I/2013/PMJ/Ditreskrimsus tertanggal 10 Januari 2013, Farhat dilaporkan atas tuduhan Pasal 28 ayat (2) UU ITE jo Pasal 4 jo 16 UU No 40 tahun 2008. Anton Medan juga melaporkan Farhat dalam laporan resmi bernopol LP/86/I/2013/PMJ/Ditreskrimsus dengan tuduhan Pasal 28 ayat (2) UU RI No 11 Tahun 2008 tentang ITE. (Sumber: OKEZONE.com, Jum'at, 24 Mei 2013 )

\section{Tahun 2014}

\section{Isu Suku - di Media Sosial Path}

Florence membuat heboh Stasiun Pengisian Bahan Bakar Umum (SPBU) di wilayah Baciro/Lempuyangan, Yogyakarta pada Rabu, 27 Agustus 2014. Wanita 26 tahun ini marah-marah karena dianggap tak mau antre saat hendak mengisi bahan bakar minyak (BBM). Ketika itu ia yang mengendarai sepeda motor masuk ke jalur mobil di bagian Pertamax 95. Kekesalan Florence pun diungkapkan melalui akun Path miliknya dengan kalimat memaki-maki Kota Pelajar tersebut.

"Jogja miskin, tolol, dan tak berbudaya.

Teman-teman Jakarta-Bandung jangan mau tinggal Jogja,"

tulis Florence dalam Path@florenceje, Kamis 28 Agustus 2014.

Berselang 2 hari, kalimat makian Florence Sihombing mengantarkan gadis 26 tahun itu pada urusan hukum. Florence ditahan setelah kasus umpatan di media sosial yang menghina Yogyakarta dilaporkanke Polda Daerah Istimewa Yogyakarta (DIY).
Dari saksi, statusnya naik menjadi tersangka.

Pada Sabtu, 30 Agustus 2014 sekitar pukul 10.30 WIB, Florence datang memenuhi panggilan pemeriksaan di Direskrimsus Polda DIY, dengan ditemani kuasa hukumnya. Namun pukul 14.00 WIB dilakukan penahanan terhadapnya. Dia akan ditahan selama 20 hari ke depan.

Florence diancam Pasal 311 KUHP Pasal 28 Ayat 2 Tahun 2008 tentang Pencemaran Nama Baik dengan ancaman hukuman penjara 4-6 tahun. Serta, Pasal 28 ayat 2 Undang-Undang Nomor 11 Tahun 2008 tentang Informasi dan Transaksi Elektronik (UU ITE) dengan ancaman maksimal 6 tahun dan/atau denda Rp 1 miliar (Sumber: news. liputan 6.com, 31 Agustus 2014)

\section{Isu Antar Golongan - di Media Sosial Facebook}

Gara-gara status di Facebook, seorang perawat di Jember, Jawa Timur, dilaporkan warga Tegalrejo Mayang ke polisi, Rabu 12 Maret 2014. FK, perawat di salah satu puskesmas di Jember, dilaporkan ke polisi karena status di akun Facebook-nya dinilai menghina dan mencemarkan nama warga Tegalrejo Mayang. FK menyebut warganya kafir dan tidak beragama.

"Tidak hanya satu status, FK menulis tiga status yang berbau SARA,"

kata Andika, warga setempat.

Inilah status Facebook FK yang membuat warga marah.

"Ironis bener Musholla dibuat diskotik, subhanallah mereka orang2 kafir yang gak tau agama, mana penjaganya anjing. Ya Rob pada gila semua,".

"Lha wong RT sama warga sini mendukung. Kalau aku lapor aku yang didemo sama warga. Pokoke semuanya gila yang gak bener malah didukung. '”

Menurut Mohammad Saha, ketua RT setempat, status tersebut muncul saat warga bergotong royong membangun sebuah musa- 
la. Untuk menyemangati warga yang membangun musala hingga malam, warga memutar musik.

"Musik tersebut yang dianggap FK sebagai diskotek."

Kaur Bin Ops Polres Jember Iptu Suhartanto membenarkan laporan warga terkait kasus penghinaan dan pencemaran nama baik melalui media sosial Facebook. Meski FK telah menghapus akun Facebook-nya, namun polisi tetap akan menyelidiki kasus tersebut dengan berbekal print out dari warga (Sumber: Viva.c.o.id, 12 Maret 2014)

\section{Isu Antar Golongan - di Media Sosial Path}

Status jejaring sosial Path berisi kebencian terhadap ibu hamil yang meminta duduk di kereta api ditulis oleh akun bernama Dinda. Mengetahui status yang ditulisnya itu menyebar di dunia maya, Dinda membeberkan alasannya.

"Path gw nyebar gara-gara statement ibu hamil ya. ayo monggo yang judge gw ngerasain dulu tiap hari naik kereta terus tiap hari berangkat abis subuh cuma biar dapat tempat duduk.

emang lo semua pada ngerti kaki gw pincang gara-gara geser tulangnya. gak kan. makanya gue bela-belain berangkat jam 5 pagi buat dapet tempat duduk. eh tibatiba ada ibu hamil baru masuk kereta jam 7 pagi. gue udah lari-larian jam 5 pagi jangan pada maunya cuma dingertiin doang para ibu.

emang gue belum hamil tapi kaki gue sakit aja gw ngerti ga mau nyusahin orang kok. plis sama-sama dong kita saling ngerti jangan mau enaknya doang ya ibu-ibu.

ayo yang ngejudge ikut saya ya berangkat dari rumah saya jam 5 naik kereta tiap hari dari rumah saya 1 kali naik ojek trus 2 kali naik angkot lho ke stasiun. ikutin aja rutinitas saya tiap hari kalau enggak ada komen apa-apa berarti saya yang berlebihan. hehe,"

kata Dinda dalam akun Path-nya.
Menurut Dinda, dirinya masih sering melihat ibu hamil lainnya berangkat pagi dan tidak pemalas. Dinda menuturkan, harusnya ibu hamil yang pemalas melihat contoh tersebut.

"Oiya, banyak juga kok ibu hamil yang gue lihat berangkat pagi juga. nah kepada enggak mencontoh mereka. mereka aja bisa kok. kalo enggak mau nyusahin enggak usah minta tempat duduk diem aja. hahahaha.. dasar pemalas. itu buktinya ada kok yang enggak pemalas. respect saya kepada ibu hamil yang mandiri dan enggak manja!!!! be tough girl!"

tambah Dinda.

Jejaring sosial Path heboh, ada remaja perempuan mencurahkan kebenciannya kepada wanita hamil yang meminta duduk saat naik kereta api. Wanita tersebut keberatan memberikan duduk karena dirinya sudah berangkat pagi demi mendapatkan kursi tersebut.

"Benci sama ibu-ibu hamil yang tiba-tiba minta duduk. Ya gue tahu lw hamil tapi plis dong berangkat pagi. Ke stasiun yang jauh sekalian biar dapat duduk, gue aja enggak hamil bela-belain berangkat pagi demi dapat tempat duduk. Dasar emang enggak mau susah.. ckckck.. nyusahin orang. kalau enggak mau susah enggak usah kerja bu di rumah saja. mentangmentang hamil maunya dingertiin terus. Tapi sendirinya enggak mau usaha.. cape dehh,"

tulis wanita itu yang bertagar \#notetomyselfjgnnyusahinorg!! (Sumber: merdeka.com, 16 April 2014)

\section{Tahun 2015}

\section{Isu Agama- di Media Sosial Facebook}

Dinilai kerap menghina Al-Qur'an dan Nabi Muhammad shallallahu 'alaihi wa sallam, Tuah Aulia Fuadi, mahasiswa semester V jurusan Ahwal Al Syakhshiyah Fakultas Syari'ah Universitas Islam Negeri (UIN) Sumut dipecat dari kampusnya.

Pemecatan tersebut disebabkan munculnya status Tuah Aulia Fuadi pada akun Facebooknya yang dinilai menghina Islam 
A (Antar Golongan) di Media Social

Indonesia

dan Al-Qur'an. Dalam postingan pada akun Facebook miliknya yang sudah dihapus itu, Tuah menuliskan kalimat seperti berikut:

"Dahulu dizaman rasul, al QURAN itu hadir dalam wajah jelek (tampil di kulit kambeng) udah lah kepalanya botak (tak berbaris) beraroma busuk pula lg itu (yg pastinya bau bangkailah). Dahulu Alquran itu memang parah, kehadirannya primitif, beda dengan sekarang.

Alquran yg sekarang sudah maju secara profresif. Ia tampil dlm wajah tampan. (di buku..."

Selain itu ia juga menulis berbagai postingan lain, misalnya:

"Penafsir tunggal itu hanya rasul dan itu pun satu. sekarang ia sudah mati jd penafsir tunggal it sdh ga ada lg. Yg sebaiknya Alquaraan itu direvisi saja. Minimal kembalikan saja urusan itu ke Negara, Biar negara saja yg merelevansikannya sesuai dengan kebutuhan zaman dan peradaban umat yg lebih progresif, modernis, teknologis dan teknogratis."

"Dalam BERNEGARA, kita tidak di wajibkan untuk mengikuti NABI MUHAMMAD langsung secara mentah2. Sebab tak ada hadis yang bunyinya, Dabbiru siyasatakum kama ra-aitumuni udabbiru siyasati, aturlah politik kalian sebagaimana kalian lihat aku mengatur politikku."

"Yang ada adalah hadis, Shallu kama ra-aitumuni ushalli, salatlah sebagaimana kalian melihat aku salat. Kenapa statemen ini hanya disabdakan Nabi dalam hal salat, dan tidak dalam lapangan politik? Jawabannya jelas: karena salat adalah masalah ubudiyyah yang statis, tidak berkembang, dan aturannya final dan terinci.

Soal politik adalah soal dinamis, dan karena dinamis maka tidak ada politik Nabi. Politik nabi pas sesuai pd zaman nya. Sementara sekarang bukan lg zaman nabi. tak SETIAP DALAM semua hal kita itu harus mengikuti Nabi."

Postingan-postingan ini sendiri terlihat sudah dihapus, namun sejumlah netizen sudah terlanjur menyalinnya. Akhirnya postingan-postingan ini membuat pihak rektorat mengambil tindakan tegas. Apalagi yang bersangkutan juga disebut pernah membanting Al-Qur'an di hadapan para juniornya saat pelaksanaan Masa Orientasi Siswa (MOS).

Tindakan mahasiswa itu sudah diperingatkan pihak rektorat, tapi kemudian dia membuka forum tersendiri di media sosial yang dinilai mencemarkan nama baik UIN. Pemecatan menjadi keputusan dari pihak Rektorat. (Sumber: salam-online.com, 24 September 2015)

\section{Isu Agama - Kasus Hujatan Perayaan Nyepi di Media Sosial Facebook}

Hujatan keras dilakukan oleh salah seorang pemuda asal Lombok, NTB, yang indekos di Denpasar Bali, Nando Irawansyah M'Ali. Dia menulis kata-kata yang menghujat perayaan Nyepi dan orang-orang Hindu Bali, pada pukul 23.59 Wita, Sabtu (21/3). Adapun isi tulisan pada statusnya yaitu.

"bener2 fuck nyepi sialan se goblok ne, $q$ jadi gak bisa nonton ARSENAL maen, $q$ sumpahin acara gila nyepi semoga tahun depan pasa ogoh2 terbakar semua yang merayakan,, fuckkkk you hindu”.

Setelah mendapat tanggapan dan hujatan sejumlah rekan-rekannya baik orang Bali maupun non Bali, Nando langsung menghapus akun hujatan yang dibuatnya. Itu dilakukan setelah dirinya menjawab dengan kata

'Asyek bentar lagi Q jadi artis'

Hujatan pedas salah satunya dari Sumerta dengan mengkritik komentar,

"Jangan dikasih hidup hewan ginian bro, yang disusul Budiawan yang berisi kata 'ini dia (diposting foto nando) bro jangan ngina agama lain, kita sebagai umat hindu jangan terpancing'.

Sementara itu, mendapat kecaman dari masyarakat Bali, Nando malah tertawa senang dan menganggap dirinya sebentar lagi jadi artis, dan seolah-olah dia tidak bersalah atas kelakuannya yang bisa saja menyakiti pe- 
meluk agama Hindu di Bali.

Salah satu organisasi pemuda Hindu Bali, Nyoman Suartha meyakinkan bahwa apa yang dilakukan Nando sesungguhnya hanya luapan kekesalan tanpa pikir panjang.

"Saya rasa orang ini tidak sadar akan apa yang telah dia perbuat. Sebagai umat Hindu yang santun, kita maafkan dan biar Tuhan yang menghukumnya. Tetapi hukum dunia harus diberlakukan agar orang -orang seperti ini tidak terus terjadi dan membuat masalah SARA,"

katanya

(Sumber: Merdeka.com, 22 Maret

2015)

Dari Data-data kasus di atas, terlihat bahwa ekpresi di media sosial dapat mengakibatkan beberapa kerugian bagi individu yang mengunggah emosinya. Selain mendapat sanksi moral dari masyarakat, mereka mendapat sanksi hukum.

Social media dalam pandangan informan merupakan representasi dari dunia nyata. Social media harusnya empowering, mendidik dan menjadi tools yang bisa memperbaiki hidup kita. Meskipun komentar yang negatif membuat orang banyak belajar untuk memperbaiki diri karena tidak semua orang senang dengan kita. Jadi, percakapan di social media dapat menjadi pembelajaran publik.

Di Indonesia, social media berada dalam tahap mencari balance. Kebebasan Pendapat masih nomor 2. Etika, sopan santun dan budaya masih menjadi ukuran nomor 1 ketika kita melakukan percakapan di social media dan harus double filttering sebelum melakukan update status. Iwan menegaskan perlu mendefinisikan arti kebebasan dalam social media karena ada konsekuensi di balik itu seperti pelanggaran hukum, pelanggaran norma-norma masyarakat. Tidak ada kebebasan yang benar-benar bebas ada poinpoin yang harus dijaga, tidak melukai hati orang, tidak menyebarkan isu-isu yang belum diketahui kebenarannya. Sebaliknya harus memberikan edukasi sosial.

Apresiasi sebagian orang terhadap etika bermedia sosial sangat rendah karena tidak ada regulasi yang langsung mengintervensi.Selain itu sosialisasi terkait dengan aturan main agar tetap pada koridor hukum juga tidak ada sehingga masyarakat pun menganggap media sosial sebagai "cerobong asap". Sebagian orang tidak memahami dampak hukum jika memakai media sosial sebagai tempat menuliskan sesuatu yang merugikan pihak lain, seperti menyebarkan fitnah, memutarbalikkan fakta, menyebarkan kabar bohong, dan lain-lain.

Menurut data penelitian tahun 2012 bahwa orang Indonesia termasuk orang yang cerewet di social media, terutama orang yang tinggal di kota Jakarta mengalahkan Tokyo, Brazil, London, San Paulo, New York. Bandung termasuk kota paling cerewet urutan keenam. Indikatornya adalah frekuensi dari tweet yang dilakukan.1.058 tweet publik sepanjang Juni 2012.

Sekitar 30\% dari populasi Indonesia aktif di media sosial dan percakapan yang paling panas akan terjadi dalam media sosial tersebut karena masyarakat lebih cenderung merujuk ke media sosial untuk mengetahui isu terkini dan perkembangan sebuah peristiwa. Kecenderungan ini otomatis mengubah cara kerja banyak profesi, tidak terkecuali wartawan dan aparat pemerintah (bbc.co.uk, 2014)

\section{Analisis Data}

Perkembangan media baru dapat didasarkan dengan cara penulisan dan penggunaan kata atau kalimat di dalam cybermedia apapun media yang digunakan. Judul dan isi dari bentuk video atau foto juga memprioritaskan penggunaan kalimat atau bahasa yang diaplikasikan dengan tujuan yang mungkin sudah dimaksudkan (Levinson, 2009:5-8).

Holmes dalam Nasrullah mengatakan kemunculan media sosial memberikan arah barut terhadap hubungan khalayak-media. Karakter media sosial adalah intraktif, 
terbuka dalam mengkreasikan konten sampai pada jaringan yang luas. Karakter dasar media sosial adalah terbentuknya jaringan antarpengguna. Jaringan ini tidak hanya memperluas hubungan pertemanan atau pengikut (follower) di internet tetapi juga membangun interaksi antarpengguna tersebut ( Nasrullah, 2015:25)

Dari hasil pengamatan, pengguna media sosial semakin meningkat dari tahun ke tahun. Penelitian sebelumnya yang berjudul The Social and Psychological Impact on Online Social Networking (2010) diutarakan bahwa atensi masyarakat memiliki kecenderungan sangat kuat dan mendasar kepada social media seperti Facebook yang hampir digunakan di seluruh dunia. Social media ini menimbulkan perasaan ketergantungan untuk selalu ingin berinteraksi dengan komunitas maya yang terbagi menjadi dua yaitu komunitas maya yang sudah dibentuk sebelumnya di dunia offline dan dilanjutkan ke dunia online. Kemudian komunitas kedua adalah komunitas baru yang dibuat sejak awal.

Social media menampilkan dua sisi yaitu kesempatan berinteraksi dan resiko penggunaan media tersebut. Keuntungan dan kerugian penggunaan social media dijabarkan dalam beberapa tahap. Salah satunya adalah keterampilan sosial di dunia maya.

Jejaring sosial memungkinkan individu bersaing dengan teman-teman yang mempunyai link yang sama dan membentuk komunitas baru. Ketika diimplementasikan secara benar, social media dapat meningkatkan harga diri dan membantu individu tersebut dari perasaan terisolasi.

Segi negatif yang ditemukan adalah berbagi informasi pribadi seseorang dengan orang yang salah. Individu perlu menyadari bahwa informasi yang diberikan secara online juga bisa menempatkan mereka pada risiko korban.

Orang yang ingin merugikan dapat menggunakan informasi yang dipublikasikan untuk mengidentifikasi mereka atau mendapat- kan kepercayaan mereka. Mereka juga bisa menipu dengan berpura-pura tahu individu tersebut. Mendorong individu untuk membuat privasi pada akun jejaring sosial online mereka seperti Facebook dan Twitter dapat mencegah atau mengurangi pengaruh negatif tersebut.

Akibat lainnya adalah bullying yaitu pelecehan dapat terjadi secara online atau cyberbullying, atau mungkin dapat berpindah menjadi intimidasi secara offline dilakukan seseorang yang mempunyai korban dan didapat secara online. Cyberbullying dapat menyebabkan kerusakan emosional yang signifikan yang mengakibatkan depresi, kemarahan, penghindaran akan kegiatan sekolah, kekerasan, dan bunuh diri.

Posting online yang ada di dunia maya tidak selalu benar adanya. Informasi dapat disebarkan bukan dari sumbernya langsung. Jadi, orang yang pernah mendengar informasi dapat menyebarluaskan kepada orang lain melalui berbagai macam social media yang mereka miliki.Gambar yang tidak pantas, keterangan, dan komentar bisa menjadi catatan baik atau mengenai individu tersebut. Sebagai contoh status anak muda yang party dengan berbagai pose yang dirasa kurang pantas akan melekat sampai nanti proses pencarian pekerjaan. Kesimpulan postingan online tidak dapat delete permanent.

Sudut pandang Dystopian melihat perkembangan media sosial dipercayai memberikan pengaruh terhadap khalayak yang semakin terpinggirkan dan melunturkan ikatan emosional karena komunikasi terjadi diperantarai dengan teknologi. Media baru dipercaya memberikan pengaruh praktik dan ruang komunikasi yang sebelumnya diperlihara secara demokratis. Internet menggeser daya fokus, kecepatan mengatasi ruang, keteraturan menjadi tidak teratur, waktu bergerak secara standar, masyarakat kehilangan pusat dan nilai-nilai yang mengatur masyarakat.

Dalam tatanan sosial, Dystopian menganggap bahwa tatanan masyarakat menjadi 
terpecah, bahkan mengisolasi interaksi satu sama lain, serta terjadinya fragmentasi akibat komunikasi yang termedia oleh media. Nilainilai yang ada di masyarakat offline menjadi kabur, bahkan tidak dapat diterapkan di dunia online (Nasrullah, 2015).

Peristiwa yang terjadi di media sosial, bila dikaitkan dengan pendapat Nasrullah dapat digaris bawahi bahwa interaksi di media sosial yang menggunakan teknologi telah melunturkan ikatan emosional. Orang bebas berekspresi di Facebook, Twitter, Path dan media sosial lainnya kapan saja. Hal yang kemudian timbul adalah respon positif dan respon negatif yang akhirnya menimbulkan konflik atau pertentangan dan bahkan menjadi masalah hukum.

\section{Isu SARA}

Terkait dengan isu SARA, Kriyantono (2012: 152) mengutarakan bahwa isu adalah berbagai perkembangan di dalam arena publik kemudian berlanjut dan berdampak lebih luas kepada masyarakat.Isu juga merupakan titik awal munculnya konflik, jika tidak mendapat pengelolaan dengan baik dan tidak sesuai dengan harapan publik seperti kebijakan, operasional, produk atau komitmen organisasi.

Penggunaan bahasa di media sosial tidak seperti di media massa umumnya. Setiap orang bebas untuk berekspresi di media sosial tanpa gate keeper atau editor seperti media massa. Dari beberapa kasus di atas yang terjadi di Indonesia interaksi di media sosial dapat menyebabkan konflik karena mereka menggunakan bahasa rasis yang menyinggung orang lain. Menurut DeVito (2011: 179) istilah bahasa rasis, artinya bahasa yang digunakan untuk menghina atau merendahkan kultur dan kebiasaan pada kultur tersebut dan mereka mempunyai istilah-istilah yang negatif.

Pesan dengan menggunakan media sosial memungkinkan untuk menimbulkan kesalahpahaman, seperti yang dialami Florence Sihombing. Kesalahan persepsi menyebabkan perbedaan makna di antara masyakat multietnis.

Peristiwa remaja perempuan mencurahkan kebenciannya kepada wanita hamil yang meminta duduk saat naik kereta api, Sosiolog dari UIN Syarif Hidayatullah Jakarta, Musni Umar menuturkan, remaja yang seperti itu masuk kategori masyarakat individualistik.

"Remaja itu termasuk orang yang tak peduli orang lain dan hanya mementingkan dirinya, itu tak seusai kultur Indonesia. Kemungkinan besar pergaulan atau bahkan keluarganya bermasalah," ujar Musni saat berbincang dengan merdeka.com, Rabu (16/4).

Di sinilah pentingnya peran etika bermedia sosial dalam keluarga, lingkungan dan pendidikan dari anak remaja.

Beberapa peristiwa tersebut di atas dapat dikaitkan dengan teori Cyberculture yang menekankan relasi antara komunikasi dan kontrol. Pesan dalam Cyberculture merupakan sebuah pesan yang memperkenalkan sebuah aksi atau reaksi.

Dari prinsip proses kontrol dan komunikasi di dalam teori Cyberculture ( Lister, dkk, 2009: 381-382), yaitu:

(1) Feedback dalam dua cara yaitu: positif dan negatif dan peristiwa di atas lebih kepada feedback yang negatif.

(2) Restriction. Menghasilkan pembatasan atas tindakan yang mencegah respon positif dan memaksimalkan respon negatif. Di Indonesia, respon atas tindakan pelaku yang menyerang SARA akan mendapat respon yang cenderung negatif pula. Tidak ada respon positif yang mendukung tindakan mencela melalui media sosial.

(3) Information varies inversely as noise. Beraneka informasi sebagai suatu kebisingan dalam interaksi. Bila suatu peristiwa sudah diungkap media, maka anggota masyarakat akan memberikan berbagai macam respon yang hampir semuanya menyerang pelaku yang mengupload pesan negatif tersebut. 


\section{Validasi Data}

Kehadiran media sosial merupakan perkembangan cara berkomunikasi maupun bersosialisasi melalui media yang disebut mediamorfosis. Invasi dari media sosial ibarat sarang laba-laba yang semakin melebar dan membentuk jaringan yang terhubung satu sama lainnya.

Menurut sumber ahli media sosial mengatakan bahwa media sosial tidak hanya sebagai media dalam bersosialisasi di Internet. Namun, memiliki aturan-aturan yang mengikat penggunanya.

Kejahatan cyber dalam penerapannya telah menggunakan undang-undang informasi dan transaksi elektronik. Sumber memberikan contohnya ditemukannya tindakan yang dengan sengaja dan tanpa hak menyebarkan informasi yang ditujukan untuk menimbulkan rasa kebencian atau permusuhan individu dan atau kelompok masyarakat tertentu berdasakan Suku, Agama, Ras dan Antar Golongan (SARA) dapat dikenakan hukuman sesuai dengan pasal 45 ayat 2 yang berbunyi:

"Setiap orang yang memenuhi unsur sebagaimana dimaksud dalam pasal 28 ayat (1) atau ayat (2) dipidana dengan pidana penjara paling lama 6 (enam) tahun dan/atau denda paling banyak Rp. 1.000.000.000,00 (satu miliar rupiah)."

Media sosial dalam pandangan Iwan merupakan representasi dari dunia nyata. Penggunaan media sosial harusnya empowering, mendidik dan menjadi tools yang bisa memperbaiki kualitas hidup. Meskipun komentar yang negatif membuat orang banyak belajar untuk memperbaiki diri. Percakapan di media sosial dapat menjadi pembelajaran publik.

Menurut Suseno yang mengatakan bahwa Etika normatif yang menetapkan sebagaimana harusnya memecahkan konflik di media sosial dengan prinsip moral dasar objektif yang dipergunakan untuk memecahkan konflik tersebut. Dasar objektif yang ditintut adalah kesadaran moral sendiri. Suara hati menuntut agar kita bertindak sesuai dengan tanggung jawab. ( Suseno, 2014:95)

Apresiasi sebagian orang terhadap etika bermedia sosial sangat rendah karena tidak ada regulasi yang langsung mengintervensi. Selain itu sosialisasi terkait dengan aturan main agar tetap pada koridor hukum juga tidak ada sehingga masyarakat pun menganggap media sosial sebagai "cerobong asap". Sebagaian orang tidak memahami dampak hukum jika memakai media sosial sebagai tempat menuliskan sesuatu yang merugikan pihak lain, seperti menyebarkan fitnah, memutarbalikkan fakta, menyebarkan kabar bohong, dan lain-lain.

Menurut pakar media sosial mengatakan bahwa curhat di media sosial dapat melegakan secara emosional dan bahkan merupakan channel yang bisa menyembuhkan orang. Namun, perlu diingatkan berpendapat di social media sangatlah mudah dan perlu diingat pula menyebarnya sangat mudah juga sehingga bisa menimbulkan berbagai macam resiko dan tak jarang berujung ke masalah hukum.

Di Indonesia, media sosial berada dalam tahap mencari balance. Kebebasan Pendapat masih nomor 2. Etika, sopan santun dan Budaya masih menjadi ukuran nomor 1 ketika kita melakukan percakapan di social media dan harus double filttering sebelum melakukan update status. Iwan menegaskan perlu mendefinisikan arti kebebasan dalam social media karena ada konsekuensi di balik itu seperti pelanggaran hukum, pelanggaran norma-norma masyarakat. Tidak ada kebebasan yang benar-benar bebas ada poin-poin yang harus dijaga, tidak melukai hati orang, tidak menyebarkan isu-isu yang belum diketahui kebenarannya. Sebaliknya harus memberikan edukasi sosial. 


\section{Penggunaan Media Sosial di Masyarakat Multietnis}

Pesan mengandung makna yang dikehendaki penyandi (encoder) dan pesan akan mengalami suatu perubahan dalam arti pengaruh budaya penyandi balik (decoder) yang telah menjadi bagian dari makna pesan. (Sihabudin, 2011:23)

Pancasila yang menjadi ideologi bangsa Indonesia, sejak awal mengakui pemikiran-pemikiran yang multikulturalis dan multietnis yang dituangkan dalam konsep Bhineka Tunggal Ika (Kresna dkk, 2013: 141). Pada masyarakat multietnis ini tentunya mempunyai cara berpikir yang berbeda sehingga penafsiran untuk sebuah peristiwa akan berbeda pula.

Seperti yang diungkapkan Kelly dalam Mulyana dan Rakhmat (2010: 84) menjelaskan mengenai proses construing atau penafsiran, didefinisikan sebagai penempatan interprestasi yang berdasarkan cara kita menafsirkan peristiwa. Selanjutnya Kelly juga mengungkapkan bahwa peristiwa yang sama dapat ditafsirkan secara berbeda.

Kelly juga berpendapat, petunjuk utama mengkontruksi realitas adalah budaya yang mengasumsikan memiliki kesamaan dalam ekspektasi yang sama dan cenderung memiliki perilaku sama pula. Kesamaan budaya pada orang-orang adalah kesamaan dalam mempersepsi apa yang mereka harapkan, (Mulyana dan Rakhmat, 2010:85).

Menurut Mulyana dan Rakhmat perbedaan sifat kesamaan kelompok ditandai dengan serangkai ekspektasi (nilai) yang sama. Setiap kelompok, betapun kecilnya, mempunyai serangkaian ekspektasi (nilai) yang berbeda untuk mempertahankan identitas kelompok. (Mulyana dan Rakhmat, 2010: 85).

Jelas dari pernyataan-pernyataan di atas bahwa setiap kelompok memiliki budaya yang berbeda menurut nilai yang mereka anut. Sebuah peristiwa akan diinterpretasi menurut ukuran atau nilai budaya mereka. Bahasa adalah cermin dari pikiran. Komunikasi yang terjadi di media sosial harus dapat memudahkan komunikasi antar budaya di seluruh dunia.

Komunikasi antarbudaya itu harusnya tidak menjadi pemicu konflik. Komunikasi harusnya dapat menyatukan Nusantara, seperti yang seringkali diucapkan Suprawito, Ketua ISKI Pusat Periode 2008-2013 pada hampir di setiap pertemuan Ikatan Sarjana Komunikasi Indonesia. Seperti yang dikatakan oleh Erving Goffman dalam Rakhmat perlu adanya pengolahan kesan agar Indonesia dikenal sebagai bangsa dengan bahasa yang santun. Sumpah pemuda juga mengingatkan bahasa Indonesia digunakan sebagai bahasa pemersatu dari masyarakat kita yang multietnis.

Konflik yang terjadi antara masyarakat Yogya dengan Florence Sihombing terjadi karena ketidaktahuan tentang keterbatasan kemampuan perceptual. Florence dianggap menggunakan bahasa rasis (DeVito, 2011:179) yaitu bahasa yang digunakan Florence menghina dan merendahkan kultur orang lain.

Di dalam komunikasi media sosial memang bebas mengungkap pesan. Namun, masing-masing etnis mempunyai pemahaman berbeda sehingga menimbulkan konflik. Kesalahan persepsi menyebabkan perbedaan makna di antara masyakat multietnis. Komunikasi itu irreversible, setiap kesan yang diberikan tidak bisa ditarik kembali. Sekalipun seseorang sudah meminta maaf tapi akan selalu melekat dalam ingatan. Sampai saat ini hanya terdapat peraturan yang tertuang dalam UU ITE no 11 tahun 2008 yang mengatur mengenai penyalahgunaan penggunaan teknologi informasi.

Menurut Dirjen Komunikasi dan Informasi Publik, UU ITE berlaku bila ada laporan dari pihak yang dirugikan.

"Kita tidak bisa menuntut pelakunya selama tidak ada yang mempermasalahkan."

Ia juga menyampaikan kepada organisasi profesi seperti Ikatan Sarjana Komunikasi (ISKI) dan Asosiasi Perguruan Tinggi Ilmu Komunikasi (ASPIKOM) untuk membantu 
pemerintah mensosialisasikan Etika dalam penyampaian pesan komunikasi di media sosial.

\section{Simpulan dan Saran}

1. Terdapat konten-konten di media sosial (Facebook, Twitter dan Path) yang berkaitan dengan isu SARA di Indonesia tahun 2014 dan tahun 2015 di berbagai daerah di Indonesia. Dari pemberitaan mengenai kasus-kasus media sosial yang mengandung isu suku, agama, ras dan antar golongan membuktikan bahwa perlu adanya etika bermedia sosial. Pemahaman mengenai media sosial. 2. Etika Bermedia sosial untuk masyarakat multietnis sangat diperlukan, meskipun curhat di media sosial dapat melegakan secara emosional dan bahkan merupakan saluran yang bisa menyembuhkan orang. Namun, perlu diingat berpendapat di social media sangatlah mudah dan perlu diingat pula menyebarnya sangat mudah pula. Resiko dari ketidapahaman terhadap etika dapat berujung ke masalah hukum.

\section{Saran}

Untuk mensosialisasikan Etika Bermedia Sosial, pemerintah perlu membuat kebijakan khusus dengan memberdayakan masyarakat melalui jalur pendidikan, komunitas dan organisasi kemasyarakat agar paham tentang etika berkomunikasi dalam penggunaan media. Caranya adalah Gerakan Etika Bermedia Sosial yang melibatkan juga peran aktif dari masyarakat dan kalangan Industri.

\section{Referensi}

\section{Buku}

Arikunto. (2005). Manajemen Penelitian. Jakarta: Rineka Cipta

Bungin, Burhan H.M.(2007). Penelitian Kua- itatif : Komunikasi, Ekonomi, Kebijakan Publik, dan Ilmu social. Jakarta : Kencana Prenama Media Group

DeVito, Joseph A. (2011). Komunikasi Antarmanusia. Edisi kelima. Tangerang Selatan: Karisma Publishing Group

Kriyantono, Rachmat. (2006). Teknik Praktis. Riset Komunikasi. Bandung: Remaja Rosdakarya.

Kresna, Aryaning Arya, Agus Riyanto dan Hendar Putranto. (2013). Pendidikan Kewarganegaraan. Edisi Revisi. Gading Serpong: UMN Press.

Levinson, Paul. (2009). New New Media. Boston: Pearson

Moleong, Lexy J.. (2008). Metodologi Penelitian Kualitatif. Bandung : Remaja Rosdakarya.

Nasrullah, Rulli. (2015). Cetakan I. Media Sosial. Prosedur, Trend, dan Etika. Bandung: Simbiosa Rekatama Media.

Mulyana, Dedy, Dr, MA dan Jalaluddin Rakhmat, Drs, M.SC (2010) Cetakan Keduabelas. Komunikasi Antarbudaya. Panduan Berkomunikasi Dengan Orang - Orang Berbeda Budaya. Bandung: Remaja Rosdakarya.

Sihabudin, Ahmad, H, Dr, M.Si.(2011). Komunikasi Antarbudaya. Satu Perspektif Multidimensi. Budaya merupakan landasan komunikasi. Bila Budaya beragam pula praktik-praktik komunikasi. Jakarta: Bumi Aksara.

Suseno, Franz Magnis (2014). Etika Dasar Masalah-masalah pokok Filsafat Moral. Yogyakarta: PT Kanisius.

Sugiyono, (2008). Metode Penelitian Kuantitatif Kualitatif dan $R \& D$. Bandung: Alfabeta.

\section{Journal}

Benedikter Roland (2012). New Media and Cultural Comsumption: Questions to Address through Public Participation. The Journal of New Media \& Cultural. 
$8(1)$

Chen, G.M. (2012). The Impact of New Media on Intercultural Communication in Global Context.China Media Research, 8(2), 1-10

Nurudin, (November, 2013). Media Sosial Baru dan Munculnya Revolusi Proses Komunikasi. Jurnal Komunikator UMY. 5 (2).127-142.

Wibowo, Indiwan,Seto. (2014). New Media dan Multikulturalisme. Jurnal Ultimacomm, 1(5), 1-10.

The social and psychological impact of online social networking: APS national psychology week survey 2010. (2010). The Australian Psychological Limited. Diakses pada 2 Desember 2014 pada laman psychology.org.au

\section{Sumber Internet}

Melissa, E. (2012). Budaya Digital dan Perubahan Konsumsi Media Masyarakat. Diakses pada 2 Desember 2014. Dari http://www.pustaka.ut.ac.id/dev25/pdfprosiding2/fisip201002.pdf

BBC Indonesia. (2014, 29 November). Media Sosial mengubah cara kerja Jurnalis. diakses 29 November 2014. Dari http://www.bbc.co.uk/indonesia/majalah/2014/11/141128_majalah_lain_ media

Tim Internet Sehat. (2014, 14 November). Korban Cyberbullying Meningkat Dua Kali Lipat. diakses 28 November 2014 pukul 5.30 WIB Dari http://internetsehat.id/2014/11/korban-cyberbullyingmeningkat-dua-kali-lipat/

Lis (Antara). (2014, 3 September). Akademisi Minta Penguna Sosial Media Perhatikan Etika. diakses pada tgl, 28 November 2015 pkl. 16.15. Dari http:// www.beritasatu.com/gadget/207060akademisi-minta-pengguna-sosialmedia perhatikan-etika.html

SosMedToday.com. (2014, 3 September). Pengguna Internet 2014, Berapa Data
Nielsen? diakses pada tanggal 28 November 2014 pukul 16.20 WIB. Dari http://sosmedtoday.com/2014/09/ pengguna-internet-2014-berapa-datanielsen/

Website Resmi Himpunan Profesi. Gamma. Sigma Beta. Institut Pertanian Bogor. Statistik: Internet, Sosial Media dan Mobile di Indonesia 2014. diakses pada tanggal 28 November 2014 pukul 16.25 WIB dari http://bebmen.com/4027/ statistik-internet-sosial-media-danmobile-di-indonesia.html

Memobee.com. (2012,31 Juli). Jakarta dan Bandung Masuk Daftar Kota Paling Sering Berkicau di Twitter. diakses Minggu, 30 November 2014 pukul 14.00 WIB. Dari http://www.memobee. $\mathrm{com} /$ jakarta-dan-bandung-masukdaftar-kota-paling-sering-berkicau-ditwitter-6991-news.html

Baranews.com. ( 2014, 3 September). 25 Kasus Status di Media Sosial yang berujung ke Ranah Hukum. diakses tanggal 30 November 2014 pkl. 16.10 WIB Dari http://baranews.co/web/ $\mathrm{read} / 20541 / 25$.kasus.status.di.media. sosial.yang.berujung.ke.ranah.hukum \#.VHrfEcnnBf8

Rmg. ( 2013, 7 November ). Kominfo: Pengguna Internet di Indonesia 63 Juta Orang, diakses 13 November 2015 dari http://kominfo.go.id/index.php/ content/detail/3415/Kominfo+\%3A + Pengguna+Internet+di+Indonesia+ $63+$ Juta + Orang/0/berita_satker\#.VkW x2E9GRdk

Ajo. (2014, 8 Mei) Kemkominfo: Pengguna Internet di Indonesia Capai 82 Juta, diakses 13 November 2015 dari http:// kominfo.go.id/index.php/content/detail/3980/Kemkominfo\%3 A+Pengguna+Internet+di+Indonesia+Capai+82+ Juta/0/berita_satker\#.VkW4a09GRdk

Oik Yusuf (2014, 24 November), Pengguna Internet Indonesia Nomor enam. diak- 
A (Antar Golongan) di Media Social

Indonesia

ses 13 November 2015 dari http://tekno.

kompas.com/read/2014/11/24/07430

087/Pengguna.Internet.Indonesia.

Nomor.Enam.Dunia

Berliyanto.(2015: April) Profil Pengguna Internet di Indonesia Tahun 2015, diakses 13 November 2015 dari http://

blog.idkeyword.com/profil-pengguna

-internet-di-indonesia-tahun-2015/ 